The role of language skills in learning to read: The case of bilingualism in French overseas departments

\author{
ISABELLE NEGRO \\ Université Nice-Sophia Antipolis
}

SOPHIE GENELOT

Université de Bourgogne

Published in Applied Psycholinguistics, Volume 33, Issue 04, October, 2012, p. 799-828

DOI: $10.1017 /$ S0142716411000579

\title{
ABSTRACT
}

This study aims to explain how the practice of two languages (French and Creole) in French overseas departments affects the first educational competencies acquired by children. The students' performance in both languages was investigated at the beginning of kindergarten, and their reading capacities were measured at the end of Grade 1 . The data analysis shows that the practice of Creole has no negative impact on success at reading in French. Furthermore, it appears that the students who performed the best in reading were those who were either more competent in French than in Creole, or those who were equally competent in both languages, according to their assessed reading competence. Thus, also discussed is the necessity of early exposure to a language's written code and the contribution that bilingualism makes to learning processes of reading.

Oral language skills acquired outside of school have an important effect on the development of fundamental educational competencies. The educational and scientific community holds broad consensus on this (Catts, Fey, Zhang, \& Tomblin, 1999; Scarborough, 2001; Savolainen, Ahonen, Aro, Tolvanen, \& Holopainen, 2008; Storch \& Whitehurst, 2002). However, the majority of these observations have been made within contexts of monolingual children whose mother tongue is also the language used in school. Departing from this point of view, then studying the situation 
for bilingual children may be more complex, and so we can explore connections that may exist between language skills and academic performance of children whose mother tongue is not the language used at school.

Studies focusing on bilingualism and its effects on learning in school generally rely on situations that contrast the learning of a first language and a second language, in which one of the languages generally dominates over the other, imposes its intonations or phonemic patterns and is spoken with more fluency, especially in late bilingualism. This dominance is less evident when a child learns both languages simultaneously and spontaneously from a very young age (Bijeljac- Babic, 2000). Under this perspective, it seems important; thus, as Kail (1983) underlines, to understand whether or not acquiring bilingualism at home offers a subsequent cognitive advantage in terms of learning fundamental skills and if so, in what ways, particularly in terms of the mastery of reading. The studies about the impact of bilingualism on school success were specifically conducted with immigrant populations and revealed that negative performance among these populations were more a result of social characteristics than of the fact that the language practiced at home was different from the one used in school (Akinci \& Jisa, 2001; Payet \& Van Zanten, 1996).

There exist other cases of bilingualism, however, corresponding to situations in which the connection between the two contact languages is more complex, situations labeled in sociolinguistics as diglossia. Historically, the term diglossia was used to refer to exceptional situations in which one language diverges into more than one variety of use (Bijeljac \& Breton, 1997). However, more generally for such situations, diglossia can be observed as being the permanent functional practice of several languages by individuals or groups living in a mixed cosmopolitan or bordering society either by those who undergo change of location or by those who share several domestic and work-based contexts. These situations are such that the two languages present, although used in complementary ways, may not be assigned the same social status, with one dominating symbolically over the other as a result of complex sociohistorical conditions (March, 1996).

In French overseas departments, populations of slaves created their own languages to communicate (i.e., Creole variations), which more or less borrowed from their first languages (i.e., various languages from the 
African continent) and from other source languages of the dominant colonizing group (i.e., French, English, Spanish). With time, the minority of people with dominant social status became generally bilingual for communication purposes, whereas the masses had difficulty accessing the reference language (i.e., French), which could only be learned in school. In the 20th century, the development of mass education allowed for the general use of both languages among younger generations in some departments, although French remained the only language taught in school. Today the coexistence of the two languages has evolved as a double system of Creole/French, to which speakers have become well accustomed. This double system is used to manage specific modes and situations of communication. Creole is used in daily and family life, French is used in various administrative or educational institutions, or a both languages may be used simultaneously. The simultaneous use of the two languages is estimated to be carried out in around 35\% of communicative spaces, whereas one or the other language is used on its own in $25 \%$ to $30 \%$ of communicative spaces (March, 1996).

In this context, the population's common perception is that the use of Creole has a detrimental effect on students' process of learning and mastering French and on their academic achievement, notably due to the close proximity and similarity of the two language codes (see for report, Giraud, Gani, \& Manesse, 1992). This representation seems to contradict data in the literature. The aim of this study is to evaluate the impact of this particular type of bilingualism on the first fundamental learning processes addressed in school, such as reading. It will also provide further knowledge about the role of oral language skills in both languages on literacy development, wherein only one of the languages is written. The findings might help to explain the situation for immigrant groups who speak one home language and are only provided literacy instruction in another dominant language.

\section{THEORETICAL FRAMEWORK}

Oral language proficiency and reading acquisition in monolinguals

Factors that have been shown to relate to monolinguals' success in reading acquisition include oral language skills (Stahl, 2003) and socioeconomic 
factors (Hart \& Risley, 1995; Snow, Burns, \& Griffin, 1998). Oral language proficiency is a complex construct that has been conceptualized and measured in different ways in studies. It comprises both receptive and expressive skills and includes various dimensions (phonology, vocabulary, morphology, syntax) that impact reading acquisition.

The best documented association in the literature addresses the role of phonological awareness on word-level reading (Cooper, Roth, Speece, \& Schatschneider, 2002; Gombert, 1990, 2003, 2006; Lonigan et al., 2009; Nation \& Snowling, 2004; Speece, Roth, Cooper, \& de la Paz, 1999; Storch \& Whitehurst, 2002). Phonological awareness would be essential for decoding words in a language based on an alphabetic principle in which each grapheme is supposed to be converted into its corresponding phoneme (Frith, 1985). Progressive exposure to the alphabetic procedure would then link reciprocally to the development of phonological awareness and particularly to phonemic awareness (Duncan, Colé, Seymour, \& Magnan, 2006; Ehri, 1991; Ehri et al., 2001; Gombert, 1990, 2003, 2006).

Another association investigated in the literature concerns the relationships between phonological awareness, language skills and reading success. According to Storch and Whitehurst (2002), language skills would have an indirect influence on the accuracy of word decoding in early elementary school. Oral language skills in kindergarten influence Grade 1 reading through the mediating effects of code- related skills in kindergarten (i.e., print principles, phonological awareness, and emergent writing); but language skills that reemerge in Grades 3 and 4 account for variance in reading comprehension. In early reading, decoding and comprehension do not constitute two different abilities because comprehension is largely dependent on word-level reading (Nation \& Snowling, 1998). In the same way, Cooper et al. (2002) show that different language skills that are measured (i.e., semantic, syntactic, and morphologic) are closely interrelated with phonological awareness; but when controlling for socioeconomic status (SES), phonological awareness accounted for unique variance in reading ability in the first grade, whereas semantic syntactic and metasyntactic knowledge did not (Bryant, MacLean, \& Bradley, 1990; Lonigan et al., 2009). The child's vocabulary is also strongly correlated itself to his or her phonological awareness (Metsala, 1999).

Other studies suggest that, on the contrary, language skills play a direct role in the success of reading, independently from the impact exerted by 
phonological awareness (Bishop, 1991; Catts et al., 1999; NICHD, 2005; Reese, Suggate, Long, \& Schaughency, 2009; Scarborough, 2001; Swanson, Rosston, Gerber, \& Solari, 2008). Catts et al. (1999) compared Grade 2 children who were either good or poor readers, based on their phonological and language skills as measured at the preschool age. The results of this study show that success as well as difficulties in decoding words are explained both by the children's level of phonological processing and by their language skills. Bishop (1991) takes into account that great importance has been attributed to phonological processing, whereas other language skills-whether syntactic or semantic-would explain an important proportion of variations in literacy scores (Nagy, Berninger, \& Abbott, 2006; Swanson et al., 2008). Morphology and syntax would be used for sentence comprehension (Swanson et al., 2008). Likewise, it would be the same issue with regards to a child's vocabulary range, which would explain the word-level reading skills that are found to be acquired in early childhood when controlling for phonological awareness (Dickinson, McCabe, Anastasopoulos, PeisnerFeinberg, \& Poe, 2003).

As pointed out by Catts et al. (1999), there is inconsistency in these studies about reading performance, being either limited to word recognition or associated to reading comprehension. Furthermore, there are inconsistencies in how oral language skills are measured. Whereas some studies give power toward vocabulary knowledge, others suggest that a more comprehensive view of language includes narrative, semantics and syntax (for a review, see Dickinson et al., 2003). The purpose in this study will be to reconcile these discrepancies in order to assess which oral language skills exert the most important impact on word recognition and on reading comprehension.

Finally, in looking at the predictors of reading, few studies have tested the effect of family characteristics, although children's oral language skills are developed primarily within the family. Their vocabulary, diverse syntactic structures, and knowledge of the world are acquired through frequent interactions with adults. Diverse play-based activities offered at home and in daily conversations in diverse informal situations within the family, more particularly interactions with one's mother, stimulate the development of a child's oral and written language skills (Beals \& Tabors, 1995; Burns, Espinosa \& Snow, 2003; Dieterich, Assel, Swank, Smith, \& Landry, 2006; Evans, Shaw, \& Bell, 2000; Hart \& Risley, 1995; Prêteur, 1998). The quality 
of these interactions depends on the mother's academic success and more generally on the family's SES (Kontos \& Wilcox-Herzog, 1997; Lesaux, Koda, Siegel, \& Shanahan, 2006). According to Bernstein (1975), families of low SES tend to use a restricted code (i.e., discourse that has a very foreseeable nature) compared to families of higher SES that prefer an elaborate code (i.e., complex language, with the vocabulary and syntactic structure of the discourse having a mildly foreseeable nature).

Studies in the section above were conducted in contexts where the child learns a written code in the same language in which he/she had previously developed oral skills. Meanwhile, the bilingual child develops different competencies than a monolingual child.

Bilingualism, oral proficiency, and reading

Bilingualism affects linguistic and cognitive performance (Bialystok, 2009). Bilinguals mentally store lexical, phonological, and syntactic units that are specific to each language and that form different subgroupings, which in turn are activated according to the language selected (De Bot \& Schreuder, 1993; Kroll, Bobb, Misra, \& Guo, 2008; Silverberg \& Samuel, 2004; for a study on cerebral neuroimaging, see also Marian, Spivey, \& Hirsch, 2003). Lexical and phonological storage may be differentiated for each language around the age of three (Bijeljac-Babic, 2000); or at least, when the second language is learned before the age of seven (Silverberg \& Samuel, 2004); or, when bilinguals become competent as such (White, Valenzuela, Kozlowska-McGregor, \& Leung, 2004). This construction of two lexical storage units specific to each language would lead to a weaker vocabulary among bilinguals compared to monolingual speakers from identical socioeconomic conditions (Bialystok \& Herman, 1999). However, bilinguals may have better conceptual knowledge shared between their two languages, which contributes to quick recovery of lexical units (Silverberg \& Samuel, 2004).

Literacy development is a complex process that combines cognitive, linguistic proficiency and print awareness, and all these skills depend on families' SES. It seems plausible in bilinguals that the intensity and length of exposure to the second language is important for the development of reading skills but a meta analysis of studies about language-minority children in the United States shows that a minimal 
exposure to English reading is necessary for there to appear equivalent reading skills between bilinguals and monolinguals (Lesaux et al., 2006). However, despite comparable performance in word identification, bilinguals generally score poorly on measures of oral language proficiency such as vocabulary.

More precisely, Gottardo (2002) investigated the relationships between firstand second-language oral proficiency and Grade 1 reading skills in SpanishEnglish bilinguals of low socioeconomic backgounds. She found that second-language word reading skills were correlated with second-language phonological processing skills, second-language vocabulary knowledge, and first-language word reading ability.

Bilinguals, compared to monolinguals, have broader phonological as well as morphologic and syntactic awareness because the practice of two languages implies an application of metacognitive abilities that are not essential to a monolingual speaker (i.e., a bilingual speaker is aware that there are several lexical units for the same signifier, as well as different word orders when expressing meanings in either language). Bilingualism would contribute positively to the development of phonological awareness (Bialystok, 1988), particularly if the languages have phonological similarities. For example, practicing both Chinese and English would be less favorable for knowledge transfer between the languages than practicing Italian and Spanish, which are phonologically more closely related (Bialystok, Luk, \& Kwan, 2005; Marian, Blumenfeld, \& Boukrina, 2008; Perdue \& Gaonac'h, 2000). A study by Campbell and Sais (1995) shows that, compared to monolingual instruction, bilingual schooling can increase bilingual students' phonological awareness, because phonological awareness in one language would be transferred into another language (Dickinson, McCabe, Clark- Chiarelli, \& Wolf, 2004) in agreement with Cummins’ (1981) interdependence hypothesis.

Thus, according to the literature, bilingualism would not be considered as a detriment, at least in word decoding. On the contrary, students could benefit from the experience of practicing a mother tongue that is different from the language of instruction but still phonologically similar. The only negative aspect that was found pertains to a weaker vocabulary in each of the two languages compared to in the language of a monolingual, which may have an effect on reading comprehension (i.e., questions about explicit and implicit relationships of meaning between sentences read). 
Verhoeven (2000) found that Moroccan or Surinamese and Antillean children who were learning Dutch as a second language performed more poorly than their monolingual Dutch peers in reading comprehension. Scores in Dutch reading comprehension in the first grade were explained by word reading efficiency and vocabulary in Dutch.

\section{Hypotheses about French-Creole}

We first hypothesized that there would be a difference between scores in French and in Creole. Creole is a particular case of bilingualism because it seems difficult to really identify which language is a second or a first language. According to March (1996), the effective use of Creole is rare in younger children and tends to increase in adolescence during conversational exchanges between peers. Then, French could be the first language and Creole the second language. However, the social representation is that Creole is the first language used in the Antilles (see Prudent, 2005), but no scientific studies attested to this fact. Nevertheless, a comparison between French-Creole bilinguals and French monolinguals showed lower scores in French language skills (vocabulary, morphology, and syntax) and cognitive tasks (working memory, ordering pictures, detecting missing details on pictures) in kindergarten bilinguals (5-yearsold) than in monolinguals ones (Negro, Genelot, \& Peslages 2006). Si Moussa (2005) also found lower academic success in second- and fourthgrade bilinguals from Réunion Island (another French department in the Indian Ocean) than in monolinguals from a town of France (Dijon). Furthermore, in primary grades, comparisons between French- Creole bilinguals and French monolinguals with regard to academic success in national evaluation tests ${ }^{1}$ confirm that there are lower levels of performance in overseas departments (Genelot, 2005; Giraud et al., 1992). If the explanation of failure in academic testing is that French constitutes a second language in French overseas departments, then bilingual children should have higher scores in Creole language tasks than in French ones, at least in vocabulary.

In contrast to the common perception that using Creole exerts a negative impact on school success, we hypothesized no negative effect of Creole

\footnotetext{
${ }^{1}$ MEN-DEP (1999). Geography of school, “les années 1990.”
} 
practice on reading performance in French, because Creole is phonologically close to French. The differences between languages lie essentially in reductions (i.e., Creole loses phonological oppositions that exist in French such as $[\mathrm{y}]$ ) and in specific rules (i.e., no vowel at the beginning of a word in Creole such as "zwézo" for "oiseau” [bird]); but globally, the phonological systems are comparable (Facthum-Sainton, 2006; Hazaël-Massieux, 2002). It follows then, as suggested in the literature, that this proximity should facilitate transfers from one language to the other (Bialystok, McBride-Chang, \& Luk, 2005; Dickinson et al., 2004; Marian et al., 2008). Children should develop phonological awareness skills via both languages by a process of linguistic interdependence (Cummins, 1981).

Finally, phonological awareness should contribute to explain word recognition (Duncan et al, 2006; Gombert, 1990, 2003). Furthermore, if the noted effect of language skills on word recognition is mediated by phonological awareness, the effect of language skills should explain no additional variance in a model of regression when phonological awareness is added (Cooper et al., 2002; Storch \& Whitehurst, 2002). Conversely, if phonological awareness and language skills exert independent effects, both should explain a variance in the regression model independently of each other (Bishop, 1991; Catts et al., 1999; NICHD, 2005; Swanson et al., 2008).

Compared to the research that has been previously carried out on this topic, the study presented in this paper is original in two ways: (a) the exposure to the written alphabetic system is only in one language, and (b) the impact of language skills on reading success is tested while controlling for SES and other individual characteristics.

\section{METHOD}

\section{Participants}

A longitudinal study was carried out from the beginning of kindergarten to the end of the first grade of elementary school in Martinique. Among the 228 children tested at the beginning of kindergarten, 199 participated in the experiment at the end of Grade 1 . The children were selected from 12 voluntary schools and 14 classes evenly distributed throughout the island 
in both urban and village contexts, in order to have variety in the families' SES. In each of these classes, teachers indicated which children came from a family context in which Creole was regularly used. All children in Martinique potentially live in a Creole context, but certain children were ruled out in the data collection according to specific information from teachers: children of families from metropolitan France, from Martinique families who do not speak Creole, and foreign families from neighboring islands. Children from metropolitan families generally understand Creole but are not born into a Creole-speaking family, so they were not retained for the study. In the same way, children of foreign nationality were also excluded from the study (i.e., Dominicans from Dominique Island, Saint Lucians), because French for them constitutes in fact "a third language" as they are English-Creole speakers and the Creole used in these other islands is different from the Creole used in Martinique.

\section{Materials and procedure}

Two different sets of tasks were drawn up and administered to the children at different points of time in their schooling. A first group of tasks was designed to evaluate preliteracy and child's characteristics in kindergarteners (i.e., language skills, phonological awareness, individual and social factors). The scores to these tasks are supposed to be predictive of reading success. Then, a second set of tasks aimed to measure reading performance in Grade 1 among the same children.

Predictive factors of reading success.

LANGUAGE SKILLS. A first group of tasks was intended to evaluate the language skills of students in French and in Creole at the beginning of kindergarten (4-5 years old). The material used (see Appendix A) was identical in both languages in order to compare students' scores in each of their languages. Three linguistic dimensions were evaluated both in production (expressive task) and in comprehension (receptive task). For each task, the comprehension score was based on the assumption that all the items that students produced were always understood by them. The comprehension score was composed of the production score plus the score from the items they had succeeded at in the comprehension task. Thus, the 
comprehension score was almost equal to or higher than the production score.

Vocabulary. Expressive vocabulary was investigated in three tasks on (a) common vocabulary, (b) space preposition, and (c) tense adverbs.

1. Common vocabulary was selected from the foundations of the acquisition scale outlined by Chalard, Bonin, Méot, Boyet, and Fayol (2003). From this scale, the vocabulary that was retained was only words that three Creolophone speakers designated as being common in Creole. The participants were then required to name twenty-one common objects drawn on pictures. The experimenter randomly showed pictures one at a time and required the child to name it.

2. For vocabulary related to space, children were instructed to successively indicate the position of 10 animals or objects in a picture using the correct preposition (i.e., behind, between, in front of, etc).

3. Concerning vocabulary related to time, children were asked to tell a story from a series of three pictures using tense adverbs, conjunctions (i.e., then, when, and, etc.).

The scores for the common words and space vocabulary corresponded to the number of correct responses, and the score for time vocabulary referred to the number of different adverbs and conjunctions correctly used to describe the pictures.

Then, to evaluate receptive vocabulary, the same items that participants had previously failed at were orally provided to them, and they were asked to demonstrate understanding of the lexical unit.

1. For common vocabulary, all the cards were displayed on the table. The experimenter named one object that was previously failed at and the child had to point it out.

2. For space vocabulary, cards were presented with the same object or animal appearing in different places, and the experimenter asked the child to show the card in which the animal "is behind the table," for example (and so on, for all the prepositions that were failed at).

3. Time vocabulary was measured by asking the child to describe or show which event corresponds to another event presented on a card, depending on sequence words such as "after," "before," and "during." the comprehension score that was calculated corresponded to the sum of the 
correct responses in each expressive vocabulary task, plus the score from the lexical items successfully demonstrated in production (because all the items that are corrrectly produced are necessarily also understood). This allowed the experimenters to reduce the number of items presented for expressive vocabulary, because of the great number of tasks already provided to kindergarteners.

Morphology. The purpose was to evaluate the participant's capacity to mark number-related meanings with specific inflections in determinants and in verbs. Verbs were selected such that inflection was phonologically audible, because most changes between singular and plural meanings are evident only in written form. The children were presented with six pictures comprising of one or multiple examples of animals or humans doing an action (three pictures with one agent and three pictures with more than one agent). For the production score, they were asked to describe the picture with a sentence consisting of a determinant, a noun and a verb. Points were acquired by providing the correct inflection for the determinant and the verb used. To assess comprehension, pictures previously failed at were presented to the children again. A double example of each picture consisted of one or several examples of the animated subjects, and the children had to match the corresponding picture with the sentence provided by the experimenter. One point was allotted for each correct response. The comprehension score was comprised of the production score plus the points acquired during the comprehension task.

Morphosyntax. The children were instructed to detect (comprehension task) and correct (production task) ten grammatical errors in oral statements (i.e., Demain il allait pêcher du poisson [Tomorrow he went fishing for fish] instead of Demain il ira pêcher du poisson [Tomorrow he will go fishing for fish]). Points were allotted for each correct response in production and in comprehension tasks.

PHONOLOGICAL AWARENESS. Phonological awareness was measured at the end of kindergarten (for details, see Negro \& Genelot, 2009) in the target language of reading learning, that is, in French (Gottardo, 2002). Phonological tasks were given to measure the children's abilities to identify the syllables and the phonemes shared among two words. The task was administered to the children individually. Each child was presented with eight series of four pictures (in two practice tests and in six experimental tests). Four series (comprising one practice test) were designed to evaluate syllable 
awareness and the other four (in one practice test) evaluated phoneme awareness. In each series, the experimenter named the four pictures. One of the pictures served as a reference, and the child had to identify among the other three pictures that one shared a syllable or a phoneme with the item in the reference picture. The common syllable/phoneme was either at the beginning, at the middle, or at the end of a word (i.e., phoneme in the middle: maison usine tortue-tambour $=$ common phoneme $[\mathrm{z}]$ ). The number of correct answers was collected.

INDIVIDUAL AND SOCIAL CHARACTERISTICS. A sociological questionnaire was drawn up in order to collect a certain amount of information about students and their families, information that took into account as many factors as possible that could significantly affect language performance and reading acquisition for the children who were tested. These "classic" variables in the sociology of education (Duru-Bellat \& Van Zanten 1999) were as follows: sex, age, method of child care, birth order, profession, level of studies pursued, certification obtained, parents' vocation, family structure (single-parent or dual-parent family), and number of long-term stays in metropolitan France. The sociological questionnaires were distributed and completed by the children's families at the beginning of kindergarten. An assistant's help was offered to families who desired it. The data was kept anonymous by means of a coding system for each child.

READING LEVEL. The purpose of these tasks was to determine students' reading level at the end of Grade 1 (6-7 years old). Two proficiencies were evaluated (for details, see Negro \& Genelot, 2009):

Word recognition. Thirty isolated words were selected in the Manulex database (Lété, Sprenger-Charolles, \& Colé, 2004) according to the frequency (frequent vs. rare) and the regularity with which a word's graphemes corresponded with its phonemes (i.e., regular or irregular, or complex items implying digraphs where more than one grapheme would correspond to one phoneme). 


\begin{tabular}{|l|c|c|}
\hline & $\begin{array}{c}\text { Frequent (Mean Frequency } \\
=\sim 393.55 / \text { million) }\end{array}$ & $\begin{array}{c}\text { Rare (Mean Frequency = } \\
\sim 25.94 / \text { million) }\end{array}$ \\
\hline Regular & Rame [row] & Lune [moon] \\
\hline Complex & Pruneau [prune] & Gateau [cake] \\
\hline Irregular & Deuxième [second] & Clown [clown] \\
\hline
\end{tabular}

The children were tested individually. Each child was requested to read aloud each word that was presented. If no response was provided after a maximum of $30 \mathrm{~s}$, the experimenter provided the next word and considered the child to have failed to read that word. One point was attributed for each correct response.

Comprehension. Comprehension was evaluated by means of four tasks extracted from the national tests administered in the first grade (2002).

The first task was composed of four series of three pictures (wherein one series was for practice). One sentence was written under each series, and the child was requested to associate the sentence with the correct picture. The task was presented individually to each child. One point was attributed for each correct response.

The following three tasks were on text comprehension and were presented to the children in groups of ten. A text composed of 75 words about a tortoise's life was written on a sheet of paper and distributed to each child. A series of questions about the text was posed under the text. Among the tasks that were meant to evaluate comprehension, three types of questions were presented to the children. First, a series of four questions was presented wherein information for the correct answer was explicitly available in the text. Each question that contained information explicitly available in the text, was to be completed by three possible pieces of information, only one of which was in the text and was correct (i.e., Quand elle a peur, la tortue rentre : sa nourriture/ses pattes/ses bébés [When she is afraid, the tortoise brings in: her food/her legs/her babies]). A second series of three questions proposed three affirmations corresponding to implicit information in the text, and the children were requested to indicate whether this affirmation was true or false (i.e., La tortue dort toute la journée: vrai ou faux [The tortoise sleeps all the day: true or false]). Finally, the last question consisted of selecting the best title for the text, among three possible titles proposed. Each correct response led to one 
point in each task.

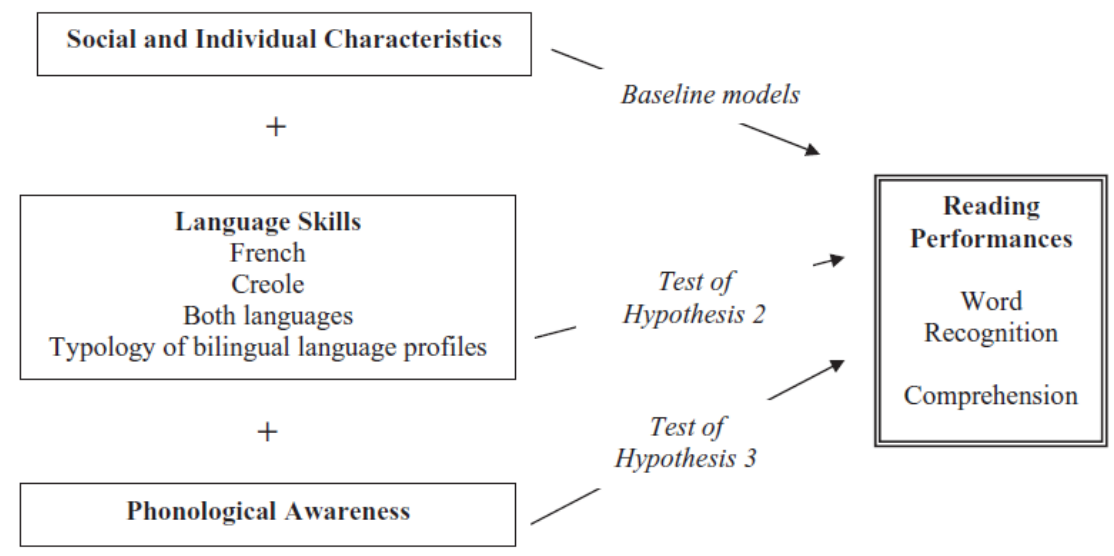

Figure 1. Regression models.

\section{RESULTS}

For each task a score was determined that corresponded to the items that had success. A proportion of correct responses, varying from 0 to 10, was then computed in each task in order to compare the data.

Briefly presented below are the intermediate results of each variable used: language skills (for further details, see Genelot \& Negro, 2007, in press), phonological awareness and reading performances (Negro \& Genelot, 2009). However, this paper focused on the impact of bilingualism on reading performance. Different regression models were then planned. Word recognition and comprehension scores were explained successively, controlling for individual and social factors, by language skills in French and/or in Creole, by a typology of bilingual language profiles and by phonological awareness that was laid out as in Figure 1.

\section{Language skills}

Intermediate analyses from the outset of kindergarten showed that Martinique children demonstrated better results in French than in Creole (see Table 1), on the whole, no matter the language dimension that was being considered: both in production, $F(1,228)=771.93, p<.01$, and in 
comprehension, $F(1,228)=, p<.01$ (see Figure 1$)$.

Table 1. Mean (0-10) and standard deviation of kindergarteners' language scores and of first graders' reading scores

\begin{tabular}{lcccc}
\hline \multicolumn{1}{c}{ Scores } & Mean & Minimum & Maximum & Standard Deviation \\
\hline $\begin{array}{l}\text { French Language skills at } \\
\text { the beginning of }\end{array}$ & 6.42 & 3.16 & 8.86 & 1.13 \\
$\begin{array}{l}\text { kindergarten } \\
\begin{array}{l}\text { Creole language skills at } \\
\text { the beginning of }\end{array}\end{array}$ & 4.26 & 1.37 & 7.57 & 1.31 \\
$\begin{array}{l}\text { kindergarten } \\
\begin{array}{l}\text { Phonological awareness at the } \\
\text { end of kindergarten }\end{array}\end{array}$ & 2.27 & 0 & 10 & 2.46 \\
$\begin{array}{l}\text { Word recognition skills at the } \\
\text { end of first grade }\end{array}$ & 6.37 & 0 & 10 & 2.74 \\
$\begin{array}{l}\text { Comprehension skills at the } \\
\text { end of first grade }\end{array}$ & 6.80 & 0 & 10 & 2.56 \\
\end{tabular}

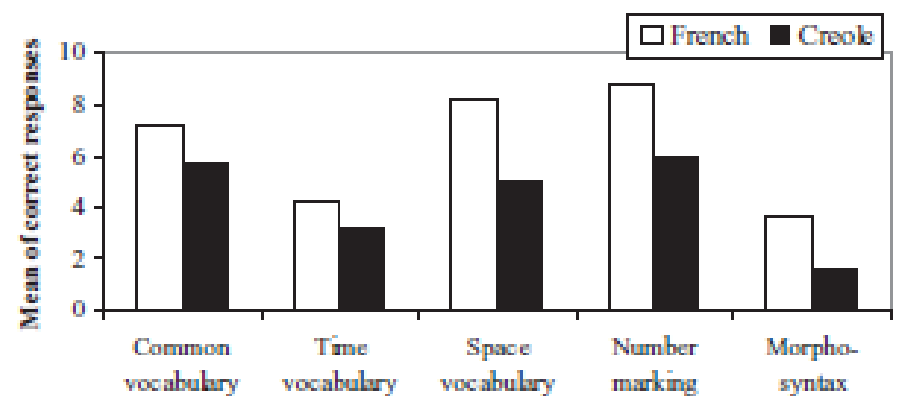

Figure 2. The mean of French and Creole language skills (mean scores in production and comprehension) according to various dimensions at the beginning of kindergarten.

When comparing the production and comprehension scores, whatever the dimensions, the children's results in Creole were particularly weak when it came to language production, even to the point of failure on certain tasks: time vocabulary, production $=1.15$ versus comprehension $=5.07$, $F(1,228)=368.58, p<.01$, and morphosyntax tasks, production $=0.43$ 
versus comprehension $=2.66, F(1,228)=92.35, p<.01$. It seems then that at this age, Martinique children's skills in expression or verbal production in Creole are lower than their comprehension skills (see Figure 2; for details, see Negro, Genelot, \& Peslages, 2005).

However, although the children were on average more proficient in French than in Creole, the results showed that their performance in both languages were significantly correlated for common vocabulary production $(r=.19, p<.05)$ and comprehension $(r=.61, p<.05)$, for space vocabulary production $(r=.28, p<.05)$ and comprehension $(r=$ $.20, p<.05)$, for time production $(r=.19, p<.05)$ and comprehension $(r$ $=.38, p<.05$ ), for number marking comprehension

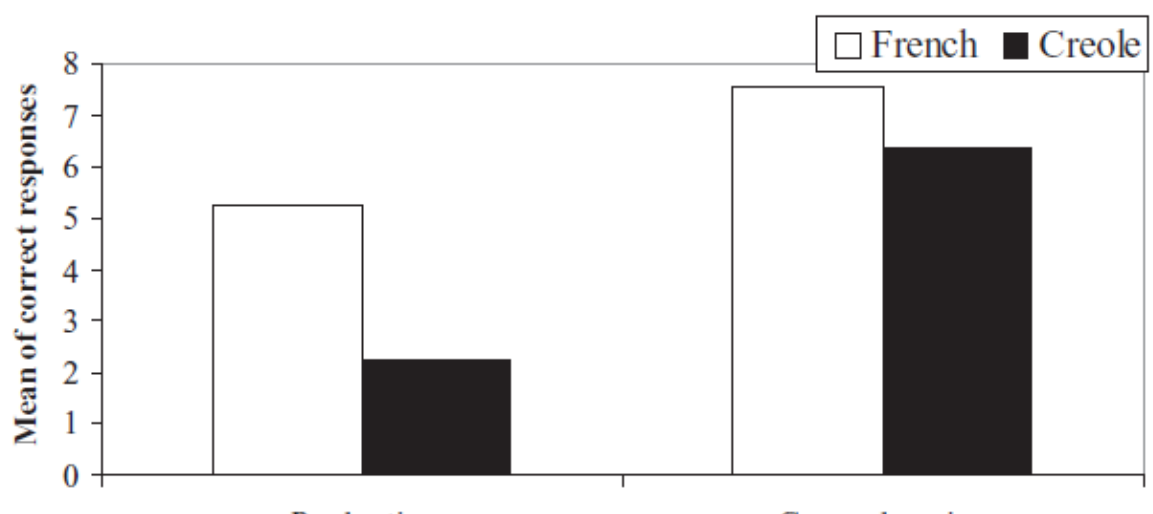

Production

Comprehension

Figure 3. Production and comprehension scores in French and Creole, whatever the linguistic dimension.

( $r=.22, p<.05)$, and morphosyntax comprehension $(r=.25, p<.05)$, whereas there was no correlation between the languages for number marking $(r=.07, n s)$ and morphosyntactic productions $(r=.13, n s)$. When a mean oral language score was computed (Figure 3 ) in French and in Creole, the correlation between both languages scores was about 0.51 ( $p$ $<.05)$.

The mastery of French surpasses that of Creole on average, but there were linguistic variations among the children. This can be illustrated by a typology of bilingual language profiles, developed by cross-referencing each child's level in French and in Creole with an overall language score, as organized into quintiles (distribution decomposed into five groups from the lower to the higher scores). Then the scores of both languages were 
crossed with each other to determine four groups of subjects as follows:

Scores in Creole Language

\begin{tabular}{|c|c|c|c|c|c|c|}
\hline $\begin{array}{c}\text { Scores in } \\
\text { French } \\
\text { Language }\end{array}$ & $\begin{array}{c}\text { Quintile } \\
1\end{array}$ & $\begin{array}{c}\text { Quintile } \\
2\end{array}$ & $\begin{array}{c}\text { Quintile } \\
3\end{array}$ & Quintile4 & $\begin{array}{c}\text { Quintile } \\
5\end{array}$ & $\begin{array}{c}\text { No. of } \\
\text { Children }\end{array}$ \\
\hline Quintile 1 & 21 & 10 & $\mathbf{3}$ & $\mathbf{6}$ & $\mathbf{1}$ & 41 \\
\hline Quintile 2 & 9 & 15 & $\mathbf{8}$ & 3 & 3 & 38 \\
\hline Quintile 3 & $\mathbf{4}$ & $\mathbf{5}$ & $\mathbf{1 0}$ & $\mathbf{1 0}$ & $\mathbf{9}$ & 38 \\
\hline Quintile 4 & $\mathbf{4}$ & $\mathbf{5}$ & $\mathbf{1 0}$ & 11 & 10 & 40 \\
\hline Quintile 5 & $\mathbf{4}$ & $\mathbf{4}$ & $\mathbf{8}$ & 9 & 17 & 42 \\
\hline Sum & 42 & 39 & 39 & 39 & 40 & 199 \\
\hline
\end{tabular}

Note: Italic indicates the number of children with low scores in both languages (55), bold indicates the number of children with higher scores in French than in Creole (54), bold italic indicates the number of children with higher scores in Creole than in French (43), and the remainder are children who had high scores in both languages (47).

1. The most sizeable group was composed of students who were more proficient in French than in Creole (28\%);

2. an almost equally important group (27\%) represented students who were weak in both languages; and

3. two other groups, each $22 \%$ of the total sample, represented students who were strong in both languages, as well as students who were more proficient in Creole than in French.

The goal of delineating this typology was to distinguish the bilingual profile that would prove to be most favorable to success in reading by the end of the first grade.

Phonological awareness

Kindergarteners' results in phonological tasks were particularly low (see Table 1). Kindergarteners had difficulties in consciously isolating the common unit between two words. Scores were only a little higher when the common unit to identify was a syllable (2.41) instead of a phoneme (2.13), but the difference was not significant $(t=1.54, n s)$. When trying to isolate either one specific syllable or one phoneme in a target word, 50\% and 53\% of kindergarteners, respectively, obtained a score of zero. From $42 \%$ to $46 \%$ 
obtained an intermediate score in these tasks, and only $4 \%$ achieved the maximum score (10).

\section{Reading scores}

The children correctly recognized on average two-thirds of the words presented, and responded correctly to two-thirds of the questions (see Table 1). The frequency, $F(1,198)=40.46, p<.01$, and the regularity, $F$ $(2,396)=426.94, p<.01$, of the lexical items exerted a significant effect on word identification. Both factors interacted such that children made more recognition errors with frequent irregular items than with rare irregular ones, $F(1,198)=77.06, p<.01$. Among the tasks that were meant to evaluate comprehension, the task that consisted of associating the sentence with the correct picture (7) led to better scores than text comprehension questions $(6.6 ; t=1.98, p<.05)$. However, within text comprehension, performance varied according to the type of question. Children responded more to questions whose responses were found explicitly in the text, successfully answering three-quarters of these on average (6.67). In contrast, for questions whose responses were implicit and required reconstruction of meaning, the children answered only one-half of such questions correctly, on average: 5.58; $(198)=3.88, p<.01$. The question that called for selecting a correct title for the text produced the best score (7.5).

The impact of bilingualism on reading level

Scores on word recognition and on comprehension were positively correlated with overall language scores in French $(r=.38$ and $r=.43$, respectively, $p<.05)$ and in Creole $(r=.29$ and $r=.31$, respectively, $p<$ $.05)$. 
Table 2. Net effects of French language skills on reading scores with given individual and social characteristics

\begin{tabular}{|c|c|c|c|c|c|}
\hline \multirow[b]{2}{*}{ Explanatory Variables } & & \multicolumn{4}{|c|}{ Dependant Variables } \\
\hline & & \multicolumn{2}{|l|}{ Word Recognition } & \multicolumn{2}{|c|}{ Comprehension } \\
\hline Mode of Reference & Active Mode & Coefficient & $\mathrm{p}$ & Coefficient & $\mathrm{p}$ \\
\hline French language skills & & +0.63 & $<.01$ & +0.77 & $<.01$ \\
\hline Age (months) & & +0.04 & ns & +0.02 & ns \\
\hline \multicolumn{6}{|l|}{ Gender } \\
\hline Male & Female & +1.24 & $<.01$ & +1.08 & $<.01$ \\
\hline \multicolumn{6}{|l|}{$\begin{array}{l}\text { Position among } \\
\text { siblings }\end{array}$} \\
\hline Eldest & $\begin{array}{c}\text { Other rank } \\
\text { among } \\
\text { siblings }\end{array}$ & +0.72 & ns & +0.85 & $<.10$ \\
\hline \multirow[t]{2}{*}{$\begin{array}{l}\text { Mother's academic } \\
\text { level }\end{array}$} & $\begin{array}{c}\text { Technical } \\
\text { certificate } \\
\text { (CAP-BEP) }\end{array}$ & & & & \\
\hline & & +0.97 & $<.05$ & -0.17 & ns \\
\hline \multirow[t]{3}{*}{ Without certificate } & Bachelor & +1.31 & $<.05$ & +0.59 & ns \\
\hline & $\begin{array}{c}\text { Bachelor +2 } \\
\text { years }\end{array}$ & +1.28 & $<.10$ & +0.71 & ns \\
\hline & $\begin{array}{c}\text { Bachelor }+3 \\
\text { years }\end{array}$ & +2.19 & $<.05$ & +1.47 & $<.10$ \\
\hline $\begin{array}{l}\text { Family with both } \\
\text { parents }\end{array}$ & $\begin{array}{l}\text { Single- } \\
\text { parent family }\end{array}$ & -0.56 & ns & -0.63 & ns \\
\hline $\mathrm{R} 2$ & & $26.15 \%$ & & $28.55 \%$ & \\
\hline
\end{tabular}

Note: CAP-BEP, Certificate d'Aptitude Professionnelle—Brevet d'Etudes Professionnelle (Vocational Training Qualification—Certificate of Professional Studies).

Multiple regression analysis patterns were then calculated to evaluate the impact of each language's scores on word recognition and comprehension, for given social and individual characteristics that were involved (see, e.g., 
Table 2). ${ }^{2}$ The models with social and individual characteristics explained $20.9 \%$ of score variations in word recognition, and $19.4 \%$ of score variations in comprehension. They constituted baseline models, to which predictive factors were added successively. The language skills evaluated at the beginning of kindergarten were significant determinants of reading level in both French (Table 2) and Creole (Table 3) at the end of Grade 1. When the language scores were added to the baseline models, language proficiency explained reading score variations in word recognition (at 5.25\% for French and 3.5\% for Creole) as in comprehension (at $9.15 \%$ for French and $5.61 \%$ for Creole). The more competent a child was in French, the more competent s/he was at reading at the end of Grade 1: the gain was +0.63 points for word recognition and +0.77 points for comprehension. The same effect was observed with regards to Creole language skills: the gain being +0.43 points for word recognition and +0.50 points for comprehension. When both languages were added to the baseline regression model to explain score variations in word recognition, the contribution of the two languages was about $6.23 \%$, but only the French language skills exerted a significant impact $(+0.50, p<.01)$. Furthermore, oral skills in both languages accounted for $10.54 \%$ of score variations in reading comprehension, and both languages had a significant impact: the gain was about +0.63 for French and +0.28 for Creole (see Table 4 ).

To clarify these first analyses, regression patterns were estimated while taking into account the typology of language profiles regarding children's skills in both languages (cf. Table 4). Compared with students who were weak in both languages, the bilingual language profiles (Table 5) that had the highest advantage for word recognition at the end of the first grade were those of students who were competent in both languages $(+1.79, p<.01)$ and those of students who were more competent in French than in Creole $(+1.44, p<.01)$. The students with higher levels of Creole than French attained results in word recognition that were weaker than the other two groups, but their results were higher than those of weak bilingual students $(+1.12, p<.05)$.

With regard to comprehension, the results were relatively close.

2 The variables retained (gender, age, position among siblings, mother's academic level, family structure) are those that had indicated an effect beforehand 
Table 3. Net effects of Creole language skills on reading scores with given individual and social characteristics

\begin{tabular}{|c|c|c|c|c|c|}
\hline & & \multicolumn{4}{|c|}{ Dependent Variables } \\
\hline \multicolumn{2}{|c|}{ Explanatory Variables } & \multicolumn{2}{|c|}{ Word Recognition } & \multicolumn{2}{|c|}{ Comprehension } \\
\hline $\begin{array}{l}\text { Mode of } \\
\text { Reference }\end{array}$ & $\begin{array}{l}\text { Active } \\
\text { Mode }\end{array}$ & Coefficient & $p$ & Coefficient & $p$ \\
\hline $\begin{array}{l}\text { Creole } \\
\text { language skills }\end{array}$ & & +0.43 & $<.01$ & +0.50 & $<.01$ \\
\hline Age (months) & & +0.05 & ns & +0.03 & ns \\
\hline \multicolumn{6}{|l|}{ Gender } \\
\hline Male & Female & +1.44 & $<.01$ & +1.34 & $<.01$ \\
\hline \multicolumn{6}{|l|}{$\begin{array}{l}\text { Position among } \\
\text { siblings }\end{array}$} \\
\hline Eldest & $\begin{array}{l}\text { Other rank } \\
\text { among } \\
\text { siblings }\end{array}$ & +0.67 & ns & +0.79 & $<.10$ \\
\hline $\begin{array}{l}\text { Mother's } \\
\text { academic level }\end{array}$ & $\begin{array}{l}\text { Technical } \\
\text { certificate } \\
\text { (CAP-BEP) }\end{array}$ & +1.01 & $<.05$ & -0.11 & $n s$ \\
\hline \multirow[t]{3}{*}{$\begin{array}{l}\text { Without } \\
\text { certificate }\end{array}$} & Bachelor & +1.50 & .01 & +0.84 & ns \\
\hline & $\begin{array}{l}\text { Bachelor +2 } \\
\text { years }\end{array}$ & +1.59 & $<.05$ & +1.12 & $<.10$ \\
\hline & $\begin{array}{l}\text { Bachelor +3 } \\
\text { years }\end{array}$ & +2.71 & $<.01$ & +2.12 & $<.05$ \\
\hline $\begin{array}{l}\text { Family with } \\
\text { both parents }\end{array}$ & $\begin{array}{l}\text { Single- } \\
\text { parent } \\
\text { family }\end{array}$ & -0.57 & ns & -0.66 & ns \\
\hline$R_{2}$ & & \multicolumn{2}{|c|}{$24.43 \%$} & \multicolumn{2}{|c|}{$25.01 \%$} \\
\hline
\end{tabular}

Note: CAP-BEP, Certificate d'Aptitude Professionnelle—Brevet d'Etudes Professionnelle (Vocational Training Qualification-Certificate of Professional Studies).

Compared with weak bilinguals, bilinguals who were competent in both languages had the best profile $(+2.02, p<.01)$ for obtaining higher scores in written comprehension.

The gain was weaker but close for bilinguals who were more competent in French than in Creole $(+1.43, p<.01)$, and vice versa $(+1.26, p<.01)$. Finally, phonological scores were added to the baseline models to explain word recognition. Phonological awareness contributed to score variations in word recognition at $1.61 \%$ (impact $=+0.14, p=.05$ ). Phonological scores were significantly correlated to French language 
ones $(r=.30, p<.05)$. A regression model was then developed to test the impact of French language skills on word recognition, while controlling for phonological levels as well as individual and social characteristics (see Table 6). This model explained $26.6 \%$ of score variations in word-level reading, and although the various language skills had a significant impact $(+0.58, p<.01)$ on success in word recognition, phonological awareness was no longer significant $(+0.08, n s)$ in this model.

Table 4. Net effects of French and Creole language skills on reading scores with given individual and social characteristics

\begin{tabular}{|c|c|c|c|c|c|}
\hline & & \multicolumn{4}{|c|}{ Dependent Variables } \\
\hline \multicolumn{2}{|c|}{ Explanatory Variables } & \multicolumn{2}{|c|}{ Word Recognition } & \multicolumn{2}{|c|}{ Comprehension } \\
\hline $\begin{array}{l}\text { Mode of } \\
\text { Reference }\end{array}$ & $\begin{array}{l}\text { Active } \\
\text { Mode }\end{array}$ & Coefficient & $p$ & Coefficient & $p$ \\
\hline $\begin{array}{l}\text { French } \\
\text { language skills }\end{array}$ & & +0.50 & $<.01$ & +0.63 & $<.01$ \\
\hline $\begin{array}{l}\text { Creole } \\
\text { language skills }\end{array}$ & & +0.25 & ns & +0.28 & .055 \\
\hline Age (months) & & +0.03 & ns & +0.01 & ns \\
\hline \multicolumn{6}{|l|}{ Gender } \\
\hline Male & Female & +1.25 & $<.01$ & +1.11 & $<.01$ \\
\hline \multicolumn{6}{|l|}{$\begin{array}{l}\text { Position among } \\
\text { siblings }\end{array}$} \\
\hline Eldest & $\begin{array}{l}\text { Other rank } \\
\text { among } \\
\text { siblings }\end{array}$ & +0.78 & ns & +0.92 & $<.05$ \\
\hline $\begin{array}{l}\text { Mother's } \\
\text { academic level }\end{array}$ & $\begin{array}{l}\text { Technical } \\
\text { certificate } \\
\text { (CAP-BEP) }\end{array}$ & +0.88 & $<.05$ & -0.27 & ns \\
\hline \multirow[t]{3}{*}{$\begin{array}{l}\text { Without } \\
\text { certificate }\end{array}$} & Bachelor & +1.23 & $<.05$ & +0.5 & ns \\
\hline & $\begin{array}{l}\text { Bachelor }+2 \\
\text { years }\end{array}$ & +1.21 & $<.10$ & +0.63 & $n s$ \\
\hline & $\begin{array}{l}\text { Bachelor +3 } \\
\text { years }\end{array}$ & +2.18 & $<.01$ & +1.46 & $<.10$ \\
\hline $\begin{array}{l}\text { Family with } \\
\text { both parents }\end{array}$ & $\begin{array}{l}\text { Single- } \\
\text { parent } \\
\text { family }\end{array}$ & -0.50 & ns & -0.57 & $n s$ \\
\hline$R_{2}$ & & \multicolumn{2}{|c|}{$27.13 \%$} & \multicolumn{2}{|c|}{$29.94 \%$} \\
\hline
\end{tabular}

Note: CAP-BEP, Certificate d'Aptitude Professionnelle-Brevet d'Etudes Professionnelle (Vocational Training Qualification-Certificate of Professional Studies). 


\section{DISCUSSION}

Regarding the status of Creole and of French, as first and second language, respectively, the first hypothesis suggesting that Creole scores would be better than French ones is not ascertained here and merits discussion. This research shows, on the contrary, that on average, French is the language that Martinique children master the best on all dimensions when entering kindergarten. This data questions with reasonable strength the status of these languages as they are normally considered at the local level: can we truly speak of a first and second language in overseas departments? It seems more that French and Creole are two languages that are present in a Martinique child's sociolinguistic environment and that these develop at differing rates (Genelot, Negro, \& Peslages, 2005). During early childhood years, French may be used more frequently by children and in a greater variety of instances than Creole. The effective use of Creole may have the tendency to develop in adolescence instead during conversational exchanges between peers (March, 1996), which explains the very low Creole scores measured here, especially in production tasks. A number of sociolinguistic studies in Réunion Island put forth moreover that there is reason to question the status of "mother tongue" or L1 attributed to Creole (Georger, 2005). The researchers either make reference to a linguistic continuum between both languages, or prioritize the interdialectic approach to account particularly for actual language practices among natives of Réunion Island, which consist specifically of phrases in French or in Creole, or phrases involving a mix of the two (see Prudent, 2005). 
Table 5. Net effects of students' bilingual language profiles on reading scores with given individual and social characteristics

\begin{tabular}{|c|c|c|c|c|c|}
\hline & & \multicolumn{4}{|c|}{ Dependent Variables } \\
\hline Explanatory Variables & & \multicolumn{2}{|c|}{ Word Recognition } & \multicolumn{2}{|c|}{ Comprehension } \\
\hline Mode of Reference & Active Mode & Coefficient & $p$ & Coefficient & $p$ \\
\hline Age (months) & & +0.04 & ns & +0.03 & ns \\
\hline \multicolumn{6}{|l|}{ Gender } \\
\hline Male & Female & +1.27 & $<.01$ & +1.15 & $<.01$ \\
\hline \multicolumn{6}{|l|}{ Position among siblings } \\
\hline Eldest & Other rank among siblings & +0.86 & ns & +0.97 & $<.05$ \\
\hline $\begin{array}{l}\text { Mother's academic } \\
\text { level Technical } \\
\text { certificate (CAP-BEP) }\end{array}$ & & +1.17 & $<.01$ & +0.05 & ns \\
\hline \multirow[t]{3}{*}{ Without certificate } & Bachelor & +1.47 & .01 & +0.82 & ns \\
\hline & Bachelor +2 years & +1.42 & $<.05$ & +0.96 & $n s$ \\
\hline & Bachelor +3 years & +2.34 & .01 & +1.73 & $<.05$ \\
\hline $\begin{array}{l}\text { Family with both } \\
\text { parents }\end{array}$ & Single-parent family & -0.49 & ns & -0.59 & ns \\
\hline Bilingual profile & $\begin{array}{l}\text { Bilingual, strong in both } \\
\text { languages }\end{array}$ & +1.79 & $<.01$ & +2.02 & $<.01$ \\
\hline \multirow[t]{2}{*}{ Weak in both languages } & $\begin{array}{l}\text { Bilingual, stronger in } \\
\text { French than in Creole }\end{array}$ & +1.44 & $<.01$ & +1.43 & $<.01$ \\
\hline & $\begin{array}{l}\text { Bilingual, stronger in } \\
\text { Creole than in French }\end{array}$ & +1.12 & $<<.05$ & +1.26 & $<.01$ \\
\hline$R_{2}$ & & \multicolumn{2}{|c|}{$\frac{1}{26.54 \%}$} & \multicolumn{2}{|c|}{$\frac{1}{27.25 \%}$} \\
\hline
\end{tabular}

Note: CAP-BEP, Certificate d'Aptitude Professionnelle—Brevet d'Etudes Professionnelle (Vocational Training Qualification—Certificate of Professional Studies). 
Table 6. Net effects of kindergarteners' French language skills and phonological awareness on word recognition, with given individual and social characteristics

\begin{tabular}{|c|c|c|c|}
\hline \multirow[b]{2}{*}{ Explanatory Variables } & & \multicolumn{2}{|c|}{ Dependent Variables } \\
\hline & & \multicolumn{2}{|c|}{ Word Recognition } \\
\hline Mode of Reference & Active Mode & Coefficient & $\mathrm{p}$ \\
\hline French language skills & & +0.58 & $<.01$ \\
\hline Phonological awareness & & +0.08 & ns \\
\hline Age (months) & & +0.04 & ns \\
\hline \multicolumn{4}{|l|}{ Gender } \\
\hline Male & Female & +1.23 & $<.01$ \\
\hline \multicolumn{4}{|l|}{ Position among siblings } \\
\hline Eldest & $\begin{array}{l}\text { Other rank } \\
\text { among } \\
\text { siblings }\end{array}$ & +0.71 & ns \\
\hline Mother's academic level & $\begin{array}{c}\text { Technical } \\
\text { certificate } \\
\text { (CAP-BEP) }\end{array}$ & +1.0 & $<.05$ \\
\hline \multirow[t]{3}{*}{ Without certificate } & Bachelor & +1.30 & $<.05$ \\
\hline & $\begin{array}{l}\text { Bachelor +2 } \\
\text { years }\end{array}$ & +1.33 & $<.10$ \\
\hline & $\begin{array}{l}\text { Bachelor +3 } \\
\text { years }\end{array}$ & +2.13 & $<.05$ \\
\hline Family with both parents & $\begin{array}{l}\text { Single-parent } \\
\text { family }\end{array}$ & -0.60 & ns \\
\hline $\mathrm{R} 2$ & & \multicolumn{2}{|c|}{$26.6 \%$} \\
\hline
\end{tabular}

Note: CAP-BEP, Certificate d'Aptitude Professionnelle-Brevet d'Etudes Professionnelle (Vocational Training Qualification-Certificate of Professional Studies).

Beyond this interpretation with regard to the respective statuses of languages in contact, the weaker levels of performance demonstrated in Creole here replicate the results of Bialystok et al. (2005). The authors noted that with English-Chinese bilinguals from 5 to 6 years old, that bilinguals' vocabulary scores were lower than those of monolingual English-speaking children; moreover, their scores were particularly weak in Chinese as well, a language only heard at home. Bilinguals are not like two monolinguals within one person: they cannot master each language at the same level of 
monolinguals because their experiences in each language are less rich. We also found in a parallel experiment that kindergarteners from Martinique obtained lower scores than kindergarteners from metropolitan France, in vocabulary as well as in all other language dimensions (for details, see Genelot \& Negro, in press; Genelot et al., 2005). Furthermore, here, when comparing oral skills among kindergarteners from Martinique, French and Creole yielded very low scores. Thus, children in Martinique presented the same pattern of performance as bilinguals described in the literature, with very low scores in both languages, because a bilingual does not constitute two monolinguals within one person (Bialystok \& Herman, 1999).

The mastery of French surpasses that of Creole on average, but the typology of bilingual language profiles that were proposed in this study also led to a good deal of heterogeneity in the results. It is possible that this variety results from an influence of social and family contexts at home, as observed via the findings that a mother's level of education affects a child's skill level attained in each language. This data may call into question the common local social representation, which holds that the intensity of one's casual Creole use decreases as one rises in the social hierarchy. Following this logic, children from the most disadvantaged social contexts should be the strongest performers in Creole. Yet the analyses reveal a reverse effect. Our results can then be interpreted as either an invalidation this social representation, or as a revelation about how Creole may be used qualitatively differently depending on social context (Genelot \& Negro, in press; Genelot et al., 2005).

The second hypothesis confirms the effect of language abilities on reading level and no negative effect of Creole. Language abilities in both French and Creole exerted significant and positive impacts both on word recognition and on reading comprehension. Both languages contributed independently to reading success; French language abilities contributed to word recognition while both languages contributed to comprehension. Moreover, the regression model that simultaneously integrates scores in both languages shows that French language skills are a more determinant factor in learning the written code than Creole language skills. This result hardly seems surprising insofar that recognizing written words implies both 
identifying the sounds that comprise a word and associating a symbolic code to each of this sound (Gombert, 2006). Compared to cases of bilingualism reported in the literature, children from Martinique only encounter the written code in French (because Creole is an oral language that is rarely written). Thus, the development of corresponding graphemephoneme connections are only made in the French code, as with the case of monolinguals. It is also possible that a child has a higher chance of identifying a word when he knows this word from a verbal context. Because written words are only encountered in French, children would benefit from having a large vocabulary in this language. This interpretation is supported by a regression model, taking into account one language dimension at a time in the model independently, and controlling for individual and social characteristics. These models show that among all dimensions measured, vocabulary contributed the best to scores in reading words (6.36\%), whereas the contribution of number morphology (2.9\%) and morphosyntax were very low $(0.42 \%)$.

With regard to capacity for comprehension, the impact of bilingualism manifests itself differently because both French and Creole exerted an effect. This effect is manifested mainly in the vocabulary scores. As in word recognition, common vocabulary in both French and Creole contributed to reading comprehension, at $9.86 \%$ and $5.92 \%$, respectively. The more words a child knows, the better he/she understands what he/she reads (NICHD, 2005; Storch \& Whitehurst, 2002). High level vocabulary in both languages would allow children to develop richer conceptual representations required to construct the meaning of a text, the comprehension being a construction between information given in the text and the reader's representation. Morphology and morphosyntax do not have the intended impact on comprehension (Swanson et al., 2008), probably because reading comprehension is tested too early in primary school and these variables emerge later with third graders (Storch \& Whitehurst, 2002). Reading comprehension scores in French in the first grade were essentially explained by word recognition in French and by French vocabulary skills (contribution $=42.22 \%$ ). This is due to the fact

that with early reading, word recognition and comprehension do not constitute two different abilities because comprehension is largely dependent on word-level reading (Nation \& Snowling, 1998; Verhoeven, 
2000).

The data with regard to the impact of the languages on reading success are supported by the typology of bilingual language profiles. The best performance in word recognition and in reading comprehension is obtained by children with high oral skills in both languages, or by children with a higher level of French than Creole. Conversely, to the social representation that asserts that the use of Creole explains low success at school in Martinique, the data here shows that Creole either has no significant impact on word recognition or contributes positively to reading comprehension.

The third hypothesis postulating an effect of phonological awareness on reading is confirmed. Phonological awareness is described as being the best predictor of word recognition (Cooper et al., 2002; Lonigan et al., 2009). The data presented here confirm the predictive power, although low, of phonological scores on word recognition. This relatively weak predictive power might result from floor effects in the phonological tasks, and from low variability between the children's scores. Moreover, the data questioned the tasks to be used to evaluate phonological awareness (Bishop, 1991; Catts et al, 1999). Some authors have recently suggested that the ability to name letters might be a better predictor than phonological awareness (Foulin, 2005; Negro \& Genelot, 2009; Scarborough, 1998; Winskel \& Widjaja, 2007). The various discrepancies between studies about the impact of phonological awareness during primary grades requires further investigation, particularly while controlling for various individual and social factors and with regards to different tasks that are proposed and labeled as "phonological tasks." However, the task used in this study was previously developed and tested as being a relevant factor in kindergartens predicting reading success at the word level in first graders (Duncan, Seymour, \& Hill, 1997; Ecalle \& Magnan, 2002). The data also attested to significant correlation between French language skills and phonological scores (Gottardo, 2002). A regression model was then computed to determine the impact of language skills, controlling for individual and social factors as well as for level of phonological awareness. Although some authors suggested that the effect exerted by oral language is mediated by phonological awareness abilities (Cooper et al., 2002; Storch \& Whitehurst, 2002), others suggest that both exert 
independent impacts on word recognition (Bishop, 1991; Catts et al., 1999; NICHD, 2005; Scarborough, 2001). This study confirms neither a mediated, nor a complementary effect. The regression pattern shows that when phonological scores and French oral scores are simultaneously added into the model, French language skills continue to have an effect, whereas phonological awareness no longer exerts an effect. In other words, children's vocabulary level and their levels of syntactic and morphological knowledge directly affect their degree of word recognition at the end of the first grade, independently of phonological awareness. Phonological awareness does not exert a complementary effect on language skills. This result reveals inconsistency with data in literature. There may be different explanations for this. First, the phonological task used here was not relevant, but as discussed earlier, it was previously used to estimate children's phonological awareness in kindergarten and in the first grade (see Ecalle \& Magnan, 2002). Second, the phonological scores were too low to exert an independent impact on language skills. These low scores could result from the fact that phonological awareness, as measured here, involves exposure to an alphabetic system. In Martinique, Creole is an oral language, and exposure to written language is essentially limited to the French alphabetic system that is studied at school. Consequently, even if Creole is phonologically close to French (Facthum-Sainton, 2006; HazaëlMassieux, 2002), this proximity is not sufficient to contribute favorably to phonological development (Cummins, 1981; Dickinson et al., 2004). The benefit of bilingualism to phonological development that is normally reported would result from exposure to both alphabetic systems. In the same perspective, Chen, Ku, Koyama, Anderson, and Li, (2008) have noted that phonological awareness increases more in the language of instruction (Mandarin) than in the language used at home (Cantonese), such that formal teaching of the alphabetic system and written code were shown to be essential to the development of phonological awareness. The Chinese dialects of Cantonese and Mandarin have a similar relationship as that of Creole and French in terms of the degrees of formality they represent, in that Cantonese is mainly an oral dialect, whereas Mandarin is more closely represented in written language and enjoys the status of being the official dialect in China. However, these languages are phonologically more different than Spanish and French, whereas French and Creole are highly 
related. Finally, this study confirms the importance of taking into account individual and social characteristics in when conducting any on language skills and learning processes in writing (Beals \& Tabors, 1995; Bowey, 1995; Burns et al., 2003; Katzir, Lesaux \& Kim, 2009; Prêteur \& Rouquette, 1992). This study suggests that a mother's level of education has a more important and direct influence on a child's language level and learning processes for writing development than social status does. Mothers, depending on their level of certification, probably do not have the same language interactions with their children (cf. Dieterich et al., 2006). It is pertinent to consider that mothers who are educated at higher levels use richer and more varied vocabulary and syntax (Bernstein, 1975) and would have a different relationship with their children than mothers who do not have educational credentials. Educated mothers would be more perceptive of early childhood literacy development and would intervene explicitly in the midst of play-based activities with their children in this sense (Ben Fadhel, 1998; Prêteur, 1998). The impact of these factors is still widely overlooked today in psychological research (Katzir, Lesaux, \& Kim, 2009). It is probable that a better test of these social factors could allow research to sift through contradictions in the literature.

\section{CONCLUSION AND PRACTICAL IMPLICATIONS}

The study presented here aimed to evaluate whether bilingualism in French over- seas departments could partially account for the weak academic results regularly observed in national assessments or research studies (Giraud et al., 1992; Si Moussa, 2001). It was under this perspective that the language skills of 199 Creole-speaking children in Martinique were evaluated in both of their languages in kindergarten, and the impact of these skills on the children's reading levels were measured at the end of the first grade.

The data presented here underline that practicing one oral language at home does not negatively affect written instruction of another formal code at school. On the contrary, it appears that bilingualism contributes positively to reading comprehension, and that exposure to the written 
code of both languages may improve phonological awareness, and subsequently, word recognition (Gombert \& Desvignes, 2002). As a result, families whose home language differs from the school language need to be encouraged to regularly practice their home language in speaking as well as in reading and in writing, in order to support success at school (Dickinson et al., 2004).

Consequently, this study brings an empirical counterperspective to the generally widespread social representation in Martinique, and offers new perspectives for school policies in French overseas departments. FrenchCreole bilingualism is probably not a major contributor to low success in school in these overseas departments. On the contrary, children who are competent in both languages would have the best chance of succeeding. In light of this, school policies should take into account the development of both languages during schooling, probably as early as kindergarten (instead of excluding one of them from the school context, as is the case now with Creole). The acceptance of Creole at school should allow children to assume their status as bilinguals and to become equally competent in both languages, which seems to be the most favorable situation for academic performance.

\section{APPENDIX A: LINGUISTICS SKILLS MATERIAL}

Vocabulary

1. Common vocabulary

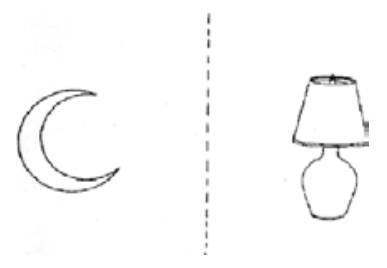

\section{Production:}

Name the object in the picture.

Dis-moi ce que c'estFrench? / Sa sa yéCreole? [Tell me what is this?] 


\section{Comprehension:}

Choose and point to the correct picture corresponding to the name of the object provided.

Où est la lune French? / Montré mwen lalin-la $_{\text {Creole }}$ ? [Show me the moon] Où est la lampe French $_{\text {? / Montré mwen lanpoul-la }}$ Creole ? [Show me the lamp]

2. Space vocabulary
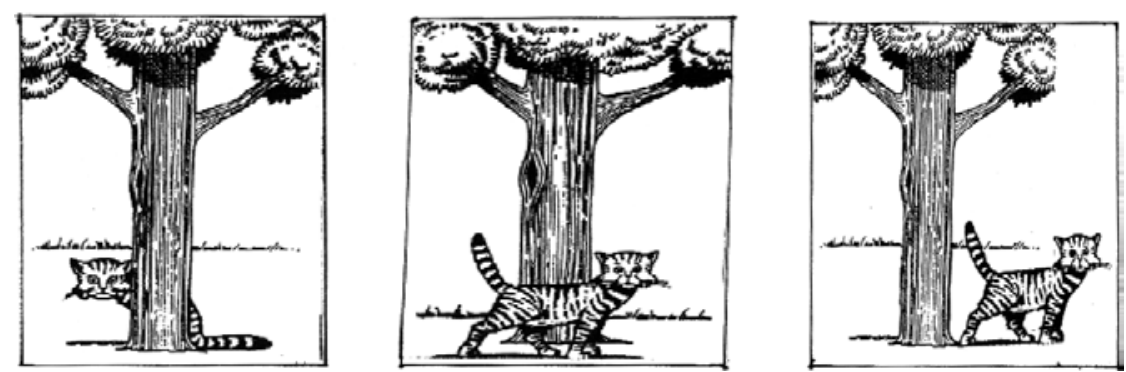

\section{Production:}

Describe how the animal (or object) is placed.

Où est le chat ici $_{\text {French }}$ ? Eti chat-la yé Creole $_{\text {? [Where is the cat }}$ here?]

\section{Comprehension:}

Choose and point to the correct picture corresponding to the preposition provided.

Regarde bien, montre-moi l'image sur laquelle le chat est derrière l'arbreFrench / Gadé bien, montré mwen chat-la ki déyè piébwaaCreole [Look at the pictures and show me the picture where the cat is behind the tree] 
3. Time vocabulary
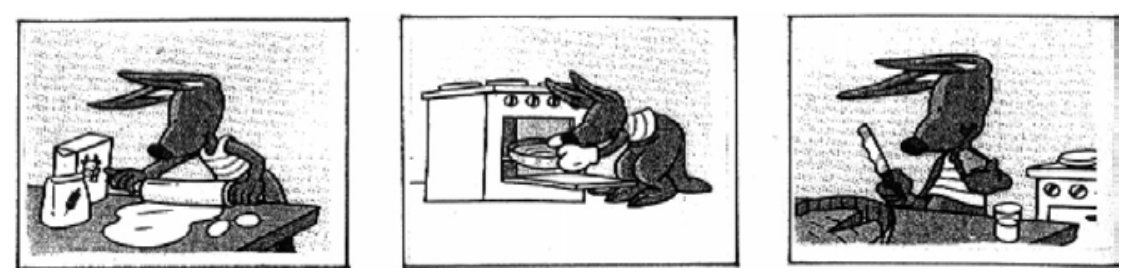

\section{Production:}

Describe the series of pictures in the order provided.

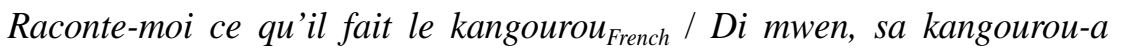
$k a$ fé ${ }_{\text {Creole }}$ [Tell me what the kangaroo is trying to do]
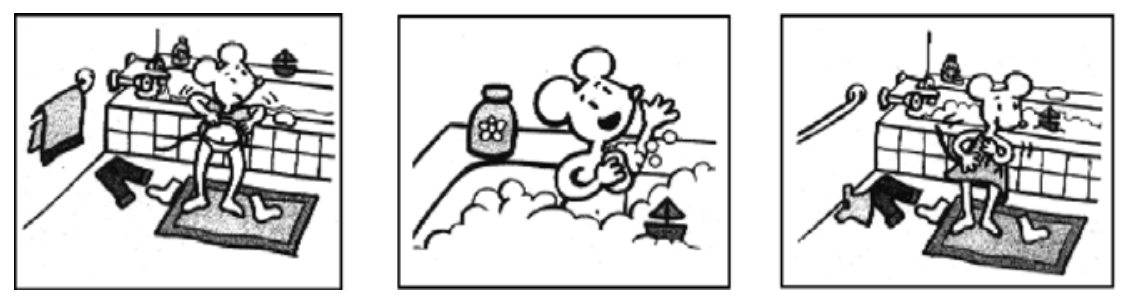

\section{Comprehension:}

Choose among the three pictures the one corresponding to the adverb or conjunction provided.

Qu'est ce que la souris a fait juste avant de prendre son bain? French / Di mwen, sa souri-a ka fé avan i benyen? Creole $_{\text {[Tell me what the mouse }}$ make before having a bath?]

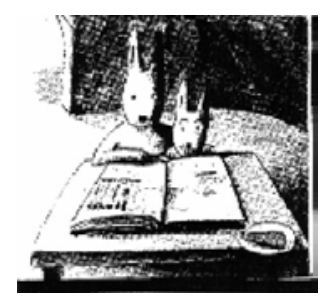




\section{Production:}

To describe the picture using the right determinant and the correct inflection to the verb.

Dis-moi qui tu vois et ce qu'il fait ou ce qu'ils font? French $_{\text {/ Ou ka di mwen }}$ sa ou ka wè épi sa i ka fé a? Creole [Tell me who you see and what he is/they are doing?]
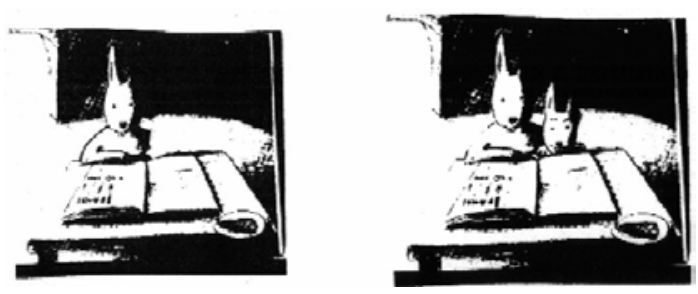

Comprehension: Choose among two pictures the one corresponding to the correct determinant and verb inflection provided.

Montre-moi sur quelle image les lapins lisent ${ }_{\text {French }}$ / Ou ka sé lapen-an ki $k a l i_{\text {Creole }}$ [Show me the picture where the rabbits are reading]

Morphosyntax

Listen to this sentence:

“Hier, il mangera chez son copain ${ }_{\mathrm{French}}$ / Yé, i ké manjé kay kanmaradli Creole

[Yesterday, he will eat at his friend's house]

\section{Comprehension:}

To be sensitive to and indicate if the sentence seems correct or incorrect.

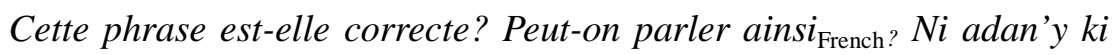
bon épi dot ki pa bon? Sé ou ki pou di mwen: i bon ouben i pa bon Creole [Is this sentence correct? Could we speak like this?] 


\section{Production:}

To correct the errors inserted in the sentence.

When the child answers "no" during the comprehension task, the experimenter asks him Alors, comment il faudrait dire French $_{\text {? / Ki mannié }}$

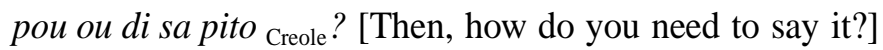




\section{ACKNOWLEDGMENTS}

We thank the children and teachers who voluntarily accepted to participate in this longitudinal study as well as Dominique Peslages, an educator at the IUFM of Martinique, for the support she provided during different stages of this research, and particularly for the advice she gave concerning the development of tasks. We also thank Robert Damoiseau and Michel Dispagne, research professors at UAG, for their participation in translating language tasks into Creole. We thank Melodie Chan for her help in translating this paper. This research represents part of a broader study entitled "Language competencies acquired in home contexts and educational acquisitions in postsecondary school: The case of Creole and French in the Martinique context.” This study was conducted within the setting of a Cognitive Science and ACI School and funded by the Ministry of Research and New Technology. 


\section{REFERENCES}

Akinci, M.-A., \& Jisa, H. (2001). Développement de la narration en langue faible et forte: Le cas des connecteurs. Acquisition et Interaction en Langue Étrangère, 14, 87-110.

Beals, D. E., \& Tabors, P. O. (1995). Arboretum, breaucratic, and carbohydrates: Preschoolers' exposure to rare vocabulary at home. First Language, 15, 57-76.

Ben Fadhel, S. E. (1998). Contexte éducatif socio-familial et acquisition de l'écrit à l'école élémentaire. Revue Française de Pédagogie, 124, 69-80.

Bernstein, B. (1975). Langage et classes sociales. Paris: Editions Minuit.

Bialystok, E. (1988). Levels of bilingualism and levels of linguistic awareness. Developmental Psychology, 24, 560-567.

Bialystok, E. (2009). Bilingualism: The good, the bad and the indifferent. Bilingualism: Language and Cognition, 12, 3-11.

Bialystok, E., \& Herman, J. (1999). Does bilingualism matter in early literacy? Bilingualism: Language and Cognition, 2, 35-44.

Bialystok, E., Luk, G., \& Kwan, E. (2005). Bilinguisme, biliteracy, and learning to read: Interactions among languages and writing systems. Scientific Studies of Reading, 9, 43-61.

Bialystok, E., McBride-Chang, C., \& Luk, G. (2005). Bilingualism, language proficiency, and learning to read in two writing systems. Journal of Educational Psychology, 97, 580-590.

Bijeljac-Babic, R. (2000). Acquisition de la phonologie et bilinguisme

précoce. In M. Kail \& M. Fayol (Eds.), L'acquisition du langage: Le langage en émergence de la naissance à 3 ans (Vol. 1, pp. 169-192). Paris: Presses Universitaires de France.

Bijeljac, R., \& Breton, R. (1997). Du langage aux langues. Paris: Editions Gallimard Découverte.

Bishop, D. V. M. (1991). Developmental reading disabilities: The role of phonological processing has been overemphasized. Mind and Language, 6, 97-101.

Bowey, J. A. (1995). Socioeconomic status differences in preschool 
phonological sensitivity and first-grade reading achievement. Journal of Educational Psychology, 87, 476-487.

Bryant, P., MacLean, M., \& Bradley, L. (1990). Rhymes, language and children's reading. Applied Psycholinguistics, 11, 237-252.

Burns, S., Espinosa, L., \& Snow, C. E. (2003). Débuts de la littératie, langue et culture: Perspective socioculturelle. Revue des Sciences de l'Education, 29, 75-100.

Campbell, R., \& Sais, E. (1995). Accelerated metalinguistic (phonological) awareness in bilingual children. British Journal of Developmental Psychology, 13, 61-68.

Catts, H. W., Fey, M. E., Zhang, X., \& Tomblin, J. B. (1999). Language basis of reading and reading disabilities: Evidence from a longitudinal investigation. Scientific Studies of Reading, 3, 331-361.

Chalard, M., Bonin, P., Meot, A., Boyer, B., \& Fayol, M. (2003). Objective age-of-acquisition (AoA) norms for a set of 230 object names in French: Relationships with psycholinguistic variables, the English data from Morrison et al. (1997), and naming latencies. European Journal of Cognitive Psychology 15, 209-245.

Chen, X., Ku, Y.-M., Koyama, E., Anderson, R. C., \& Li, W. (2008). Development of phonological awareness in bilingual Chinese children. Journal of Psycholinguistic Research, 37, 405-418.

Cooper, D. H., Roth, F. P., Speece, D. L., \& Schatschneider, C. (2002). The contribution of oral language skills to the development of phonological awareness. Applied Psycholinguistics, 23, 399-416.

Cummins, J. (1981). The role of primary language development in promoting educational success for language minority students. In California State Department of Education (Dir.), Schooling and language minority students: A theoretical framework (pp. 349). Los Angeles: California State University, Evaluation, Dissemination and Assessment Center.

De Bot, K., \& Schreuder, R. (1993). Word production and the 
bilingual lexicon. In R. Schreuder \& B. Weltens (Eds.), The bilingual lexicon (pp. 191-214). Amsterdam: John Benjamins.

Dickinson, D., McCabe, A., Anastasopoulos, L., Peisner-Feinberg, E., \& Poe, M. (2003). The comprehensive language approach to early literacy: The interrelationships among vocabulary, phonological sensitivity, and print knowledge among preschoolaged children. Journal of Educational Psychology, 95, 465-481.

Dickinson, D. K., McCabe, A., Clark-Chiarelli, N., \& Wolf, A. (2004). Cross-language transfer of phonological awareness in low-income Spanish and English bilingual preschool children. Applied Psycholinguistics, 25, 323-347.

Dieterich, S. E., Assel, M. A., Swank, P., Smith, K. E., \& Landry, S. H. (2006). The impact of early maternal verbal scaffolding and child language abilities on later decoding and reading comprehension skills. Journal of School Psychology, 43, 481-494. Duncan, L. G., Colé, P., Seymour, P. H. K., \& Magnan, A. (2006). Differing sequences of metaphonological development in French and English. Journal of Child Language, 33, 369-399.

Duncan, L. G., Seymour, P. H. K., \& Hill, S. (1997). How important are rhyme and analogy in beginning reading. Cognition, 63, 171208.

Duru-Bellat, M., \& Van Zanten, A. (1999), Sociologie de l'école. Paris: Editions Armand Colin.

Ecalle, J., \& Magnan, A. (2002). The development of epiphonologocal and metaphonological processing at the start of reading: A longitudinal study. European Journal of Psychology of Education, 17, 47-62.

Ehri, L. C. (1991). Learning to read and spell words. In L. Rieben \& C. Perfetti (Eds.), Learning to read: Basic Research and its implications (pp. 57-73). Hillsdale, NJ: Erlbaum.

Ehri, L. C., Nunes, S. R., Willows, D. M., Schuster, B. V., Yaghoub Zadeh, Z., \& Shanahan, T. (2001). Phonemic awareness instruction helps children learn to read. Evidence from the National Reading Panel's meta-analysis. Reading Research 
Quarterly, 36, 250-287.

Evans, M. A., Shaw, D., \& Bell, M. (2000). Home literacy activities and their influence on early literacy skills. Canadian Journal of Experimental Psychology, 54, 65-75.

Facthum-Sainton, J. (2006). Les langues créoles à base lexicale française de la Caraïbe: Phonétique, phonologie et variation. Thèse de doctorat. Paris: É cole Pratique des Hautes Études.

Foulin, J.-N. (2005). Why is letter-name knowledge such a good predictor of learning to read? Reading and Writing, 18, 129-155.

Frith, U. (1985). Beneath the surface of developmental dyslexia. In K. Patterson, J. C. Marshall \& M. Coltearth (Eds.), Surface dyslexia (pp. 301-330). London: Routledge \& Kegan Paul.

Genelot, S. (2005). L'école à la Martinique, état des lieux. In F. Tupin (Ed.), Ecoles ultramarines. Univers Créoles 5 (pp. 3-22). Paris: Anthropos, Economica.

Genelot, S., \& Negro, I. (in press). Contribution à l'analyse des inégalités territoriales de réussite à l'école primaire. Performances langagières et cognitives d'élèves de GS en Martinique et en France métropolitaine. Revue Française de Pédagogie.

Genelot, S., \& Negro, I. (2007). Bilinguisme familial et acquisitions scolaires: Le cas des départements d'outre-mer français (DOM). In P. Marquet, N. Hedjerassi, A. Jarlegan, E. Pacurar, \& E. Remoussenard (Eds.), Actualité de la Recherche en Education et Formation [CD].

Genelot, S., Negro, I., \& Peslages, D. (2005). Compétences bilingues Français/Créole chez des enfants de 5 ans en contexte martiniquais. Etudes Créoles, 28, 41-66.

Georger, F. (2005). Le réunionnais au secours du créole et du français à l'école. Etudes Créoles, 28, 119-146.

Giraud, M., Gani, L., \& Manesse, D. (1992). L'école aux Antilles: Langues et échec scolaire. Paris: Editions Karthala.

Gombert, J. E. (1990). Le développement des capacités métalinguistiques. Paris: Presses Universitaires de France. 
Gombert, J.-E. (2003). Implicit and explicit learning to read: Implication as for subtypes of dyslexia. Current Psychology Letters: Behavior, Brain and Cognition, 10. Retrieved from http://cpl.revues.org/index202.html

Gombert, J.-E. (2006). Epi/méta vs. implicite/explicite: Niveau de contrôle cognitif sur les traitements et apprentissage de la lecture. Langages et Pratiques, 38, 68-76.

Gombert, J.-E., \& Desvignes, J. (2002). Lecture. In M. Colmant, J.-P. Jeantheau, \& F. Murat (Eds.), Les compétences des élèves à l'entrée au CP. Etudes réalisées à partir du panel d'écoliers recrutés en 1997: Les dossiers (Vol. 132, pp. 54-63). Paris: Ministère de l'Education Nationale et de la Recherche.

Gottardo, A. (2002). The relationship between language and reading skills in bilingual Spanish-English speakers. Topics in Language Disorders, 22, 46-70.

Hart, B., \& Risley, T. (1995). Meaningful differences in the everyday experience of young American children. Baltimore, MD: Paul H. Brookes.

Hazaël-Massieux, M. C. (2002). Les créoles à base française: Une introduction. Travaux Interdisciplinaires du Laboratoire Parole et Langage, 21, 63-86.

Kail, M. (1983). L'acquisition du langage repensée: Les recherches interlangues. L'Année Psychologique, 83, 225-258, 561-596.

Katzir, T., Lesaux, N. K., \& Kim, Y.-S. (2009). The role of reading self-concept and home literacy practices in fourth grade reading comprehension. Reading and Writing, 22, 261-276.

Kontos, S., \& Wilcox-Herzog, S. (1997). Teacher's interaction with children: Why are they so important? Young Children, 52, 4-12.

Kroll, J. F., Bobb, S. C., Misra, M., \& Guo, T. (2008). Language selection in bilingual speech: Evidence for inhibitory processes. Acta Psychologica, 128,416-430.

Lesaux, N., Koda, K., Siegel, L., \& Shanahan, T. (2006). Development of literacy: Meta analysis. In D. August \& T. Shanahan (Eds.), 
Developing literacy in second-language learners: Report of the National Literacy Panel on Language-Minority Children and Youth (pp. 75-122). Mahwah, NJ: Erlbaum.

Lété, B., Sprenger-Charolles, L., \& Colé, P. (2004). Manulex: A grade-level lexical database from French elementary-school readers. Behavior Research Methods, Instruments, and Computers, 36, 156-166.

Lonigan, C. J., Anthony, J. L., Phillips, B. M., Purpura, D. J., Wilson, S. B., \& McQueen, J. D. (2009). The nature of preschool phonological processing abilities and their relations to vocabulary, general cognitive abilities, and print knowledge. Journal of Educational Psychology, 101, 345-358.

March, C. (1996). Le discours des mères martiniquaises: Diglossie et créolité, un point de vue socio- linguistique. Paris: Editions L'harmattan.

Marian, V., Spivey, M., \& Hirsch, J. (2003). Shared and separate systems in bilingual language processing: Converging evidence from eye-tracking and brain imaging. Brain and Language, 86, 70-82.

Marian, V., Blumenfeld, H. K., \& Boukrina, O. V. (2008). Sensitivity to phonological similarity within and across languages. Journal of Psycholinguistic Research, 37, 141-170.

Metsala, J. L. (1999). Young children's phonological awareness and non-word repetition as a function of vocabulary development. Journal of Educational Psychology, 91, 3-19.

Nagy, W., Berninger, V. W., \& Abbott, R. D. (2006). Contributions of morphology beyond phonology to literacy outcomes of upper elementary and middle-schools students. Journal of Experimental Psychology, 98, 134-147.

Nation, K., \& Snowling, M. (1998). Semantic processing and the development of word recognition skills: Evidence from children with reading comprehension difficulties. Journal of Memory and Language, 39, 85-101. 
Nation, K., \& Snowling, M. J. (2004). Beyond phonological skills: Broader language skills contribute to the development of reading. Journal of Research in Reading, 27, 342-356.

Negro, I., \& Genelot, S. (2009). Les prédicteurs en grande section maternelle de la réussite en lecture en fin de premiè̀e année de l'école primaire: L'impact du nom des lettres. Bulletin de Psychologie, 62, 291-306.

Negro, I., Genelot, S., \& Peslages, D. (2005). Interaction between family languages and languages of schooling: The case of French and Creole in Martinique kindergartners. Paper presented at the EARLI Biennial Conference, University of Cyprus.

Negro, I., Genelot, S., \& Peslages, D. (2006). Compétences langagières acquises en milieu familial et acquisitions scolaires en cycle 2: Le cas du créole et du français en contexte martiniquais. Rapport de recherche. ACI Ecole et Sciences Cognitives, Ministère délégué à la recherche et aux nouvelles technologies.

NICHD Early Child Care Research Network. (2005). Pathways to reading: The role of oral language in the transition to reading. Developmental Psychology, 41, 428-442.

Payet, J.-P., \& van Zanten, A. (1996). L’école, les enfants de l'immigration et des minorités ethniques. Une revue de la littérature française, américaine et britannique. Revue Française de Pédagogie, 117, 87-149.

Perdue, C., \& Gaonac'h, D. (2000). Acquisition des langues secondes. In M. Kail \& M. Fayol (Eds.), L'acquisition du langage: Le langage en développement au delà de 3 ans (Vol. 2, pp. 215-246). Paris: Presses Universitaires de France.

Prêteur, Y. (1998). Education familiale et développement du rapport à l'écrit et à l'école. Les Dossiers d'Education et Formations, 101, 69-92.

Prêteur, Y., \& Rouquette, L. (1992). L’incidence d’une pédagogie fonctionnelle autour du livre de jeunesse sur les compétences 
orales et écrites d'enfants de GSM de milieux sociaux contrastés. Revue Française de Pédagogie, 98, 29-40.

Prudent, L. F. (2005). L'école martiniquaise à la recherche de sa cohérence. In F. Tupin (Ed.), Ecole ultramarine, Univers Créoles (Vol. 5, pp. 23-46). Paris: Editions Economica Anthropos.

Reese, E., Suggate, S., Long, J., \& Schaughency, E. (2009). Children’s oral narrative and reading skills in the first 3 years of reading instruction. Reading and Writing, 23, 627-644.

Savolainen, H., Ahonen, T., Aro, M., Tolvanen, A., \& Holopainen, L. (2008). Reading comprehension, word reading and spelling as predictors of school achievement and choice of secondary education. Learning and Instruction, 18, 201-210.

Scarborough, H. S. (1998). Early identification of children at risk for reading disabilities: Phonological awareness and some other promising predictors. In B. K. Shapiro, P. J. Accardo, \& A. J. Capute (Eds.), Specific reading disability: A view of the spectrum (pp. 77-121). Timonium, MD: York Press.

Scarborough, H. S. (2001). Connecting early language and literacy to later reading (dis)abilities: Evidence, theory and practice. In S. B. Neuman \& D. K. Dickinson (Eds.), Handbook of early literacy research (pp. 97-110). New York: Guilford Press.

Silverberg, S., \& Samuel, A. G. (2004). The effect of age of second language acquisition on the representation and processing of second language words. Journal of Memory and Language, 51, 381-398.

Si Moussa, A. (2001). Evaluation et analyse des acquisitions des élèves en CE1 et CM1. Rapport de recherche "Charte pour l'école du XXIème siècle:” Mission Ecole primaire. Paris: INRP.

Si Moussa, A. (2005). Evaluation et déterminants de la réussite scolaire. In A. Si Moussa (Eds.), L'école à la Réunion, approches plurielles (pp. 51-84). Paris: Karthala.

Snow, C. E., Burns, M. S., \& Griffin, P. (Eds.). (1998). Preventing reading difficulties in young children. Washington, DC: National 
Academy Press.

Speece, D. L., Roth, F. A., Cooper, D. H., \& de la Paz, S. (1999). The relevance of oral language skills to early literacy: A multivariate analysis. Applied Psycholinguistics, 20, 167-190.

Stahl, S. S. (2003). Vocabulary and readability: How knowing word meanings affects comprehension. Topics in Language Disorders, 23, 241-247.

Storch, S. A., \& Whitehurst, G. J. (2002). Oral language and coderelated precursors to reading: Evidence from a longitudinal structural model. Developmental Psychology, 38, 934-947.

Swanson, H. L., Rosston, K., Gerber, M., \& Solari, E. (2008). Influence of oral language and phonological awareness on children's bilingual reading. Journal of School Psychology, 46, 413- 429.

Verhoeven, L. T. (2000). Components in early second language reading and spelling. Scientific Studies of Reading, 4, 313-330.

White, L., Valenzuela, E., Kozlowska-McGregor, M., \& Leung, Y. K. I. (2004). Gender and number agreement in nonnative Spanish. Applied Psycholinguistics, 25, 105-133.

Winskel, H., \& Widjaja, V. (2007). Phonological awareness, letter development, and literacy development in Indonesian beginner readers and spellers. Applied Psycholinguistics, 28, 23-45. 